\title{
A Study of the Ancient Turks Family*
}

\section{Vladimir V. Tishin}

Institute of Mongolian, Buddhist, and Tibetan Studies, Siberian Branch of the Russian Academy of Sciences

\begin{abstract}
This article discusses the form of the Ancient Turks family in the context of original source data. The conclusions of the Marxist scholars were mostly artificial and speculative, while in the rest of the scientific world the problem received little attention. Through consideration of the issues under discussion, involving original source data, the author points to a nuclear form of the Ancient Turks family, which is typical of nomadic societies in general.
\end{abstract}

The problem of family organization as a social institution of nomadic societies has remained relevant throughout all periods of the study of nomadism. However, the views of scientists on the form of family of nomads had evolved in the context of the enlargement of both the source and methodological bases used for these studies. The family institution in the social life of Inner Asian nomads of the Old Turks Period (the sixth - the tenth centuries AD), and of the Türks in particular ${ }^{1}$, have not yet become a subject of special research, although they have been touched upon by researchers in the context of various problems of the social history both of the Türks or other nomadic societies.

Under the influence of Marxism, an evolutionary stadial approach to the study of socio-economic relations among nomads was established in historiography, according to which nomadic economic activity and societal structures of nomads were considered on the basis of ideas about the existence of unified scheme of the historical process. Therefore, based on the classic work of Friedrich Engels Der Ursprung der Familie, des Privateigenthums und des Staats, Aleksandr N. Bernshtam argued that the main economic unit among the Türks was a patriarchal family (Bernshtam 1946: 88, 94). This idea was further supported by other Soviet researchers (Abramzon 1951: 152-155; Lashuk 1967: 119; Markov 1976: 79; etc.). Sergei P. Tolstov wrote about 'large patriarchal families characterized by

Social Evolution \& History, Vol. 18 No. 2, September 2019 115-132

(C) 2019 'Uchitel' Publishing House

DOI: $10.30884 / \mathrm{seh} / 2019.02 .06$ 
polygamy, a developed institution of adoption and ... a highly developed clientela' (Tolstov 1938: 32; 1948: 264).

Sergei G. Klyashtorny also adhered to the traditional idea that 'the basic cell of production of any nomadic society', including the Türkic one, was the 'family household.' However, he characterized it as being patriarchal (Klyashtorny 2003: 483; etc.). Lev N. Gumilyov believed that the Türks had a pairing family (Gumilyov 1967: 70, 74), although in another passage, discussing the Tiělè 鐡勒 tribes, he wrote about 'large families' and about the tranformation of those 'large families' into tribes (Ibid.: 61).

In the opinion of Yury A. Zuev, originally 'the smallest economic unit and the basis of the social structure of the ancient Turks society was a large-family community, whose obligatory attributes were a common dwelling (at an early stage), a common pot, and a patriarch-housekeeper' (Zuev 1967: 71; 1977: 331). His argument in favor of this was found in sources discussing cattle, which requires stabling, and their presence thus implies a sedentary way of life for the Türks (Idem 1967: 72).

Zuev based this passage on chapter 197 of the Tōng Diăn 通典 (801) in which he translated the Türkic title Yi kèhán 遺可汗, 'house kagan' (Ibid.: 71-72; 1977: 331): Yì yǒu kèhán wèi zài yèhù xiàhuò yǒu jūjiā dàxìng xiāng hū wéi yí kèhán zhě tūjué hū wū wéi yíyán wū kèhán yě 亦有可汗位在葉護下或有居家大姓相呼為遺可 汗者突厥呼屋為遺言屋

可汗也 (cited in Taşağıl 2003a: 200 [Tōng Diăn, ch. 197, p. 1068a, lines 21-23]). The identification of the character $y i$ 遺 as the Turks word $\ddot{a} b$ or $\ddot{a} v$ ('house') was proposed in 1958 by Liu Mau-Tsai (1958: 9, 498499 [Anm. 49]). He translated the passage in the following: 'Es gab auch Khagane die im Range niedriger standen als der Ye-hu (Yabgu). Es kam auch vor, dass grosse zu haus bleibende, also nicht amtierende Familien sich gegenseitig I Khagan 遺可汗 nannten. Die T'u-küe sagten für den Raum (order das Haus 屋) I [M. ywil] (alttürkisch- äb äv). Der Titel bedeutete also Raum- (oder Haus-) Khagan,' However, this translation was criticized by Zuev who noted the absence of the phrase 'large families, stayed at home, i.e. did not officiate' (Zuev 1998: 159; 2002: 289) in the Chinese text. In Zuev's first variant of translation it read '...it happens that living in houses (or families, Chin. jiā) in large families call each other "uv-qayan"; a house is called by the Türks the $u v$, and that means house qayan' (Zuev 1967: 71-72). His later translation of the same text read: 'There are qayans of lower rank than yabyu. It happens also that living in families in large genera (originally: rodami) called their head $u y$ qayan; a house is called by the Türks the $\ddot{u} y$; that means house qayan' (Zuev 1977: 331). The translation proposed by Vsevolod S. Taskin is still 
different: 'There are also qayans [standing] at a lower position than yèhù, and there are representatives of large families living at home who call each other yí kèhán (qayan). Tüjué call the house yí, and that denomination means the house qajan' (Taskin 1984a: 68, 305 [commentary 46]).

Taskin noted that the symbol yi 遺 also could be read like $y u ́$ 于, connecting it to the Turkic word $\ddot{u} y$ 'house', and argued that the phrase yú kèhán was used to describe the head of one's own family or clan (Ibid.: 68, 306 [commentary 46]). However, the form $\ddot{u} y$ has been described in more recent sources as the result of phonetic transformation (see Sevortian 1974: 513-515).

According to Zuev, after the Türks had transitioned to a nomadic lifestyle, an 'autonomization' of individual families occurred within the community, and this process contributed to its disintegration, but not the loss of ties between those small families. As a result of this process, the commonality of the community economy was violated, the large-family community, being incompatible in its classical form with a nomadic economy, began to transform into a patronymy (Zuev 1967: 80-83, 194). In the patriarchal large-family community, the reckoning of both maternal and paternal kinship was preserved due to the significant role women played in the nomadic economy, or the specificity of relations between clan-tribal groups. The patriarchal type of a family did not have the chance to become entrenched, because of the changing conditions of the economy and the features of social ties (Ibid.: 83-84).

One of the arguments in favor of the changing Türks economy hypothesis, according to Zuev, is the emergence among them of a new type of dwelling namely, the yurt (käräkü; Rus. yurta) (Ibid.: 77-79). He considers the qiónglú 穹盧 mentioned in Chinese sources to be a description of large yurts, remnants from times when huts had been the main type of dwelling (Ibid.: 74-75, 76). Zuev refers to information on the nomadic peoples of earlier eras or cites data from the Tàiping huányǔ jì 太平寰宇記

on Qïrqïz (Xiájiásī 黠戛斯) people who were described as 'having a common house, one bed, one blanket' (Kyuner 1961: 60). However, the early qiónglú 穹盧 (literally 'domed hut') during the period of the Xiōngnú

匈奴 was a domed wicker hut with a felt roof covering (Weinstein 1976: 46; 1993: 45-50; Weinstein and Kryukov 1976: 146-147; Kryukov 1988: 234 (note 2); Kryukov and Kurylev 2000: 10-11). ${ }^{2}$

Based on written, archaeological and imaginative sources, Soviet ethnologists concluded that the invention of the yurt with a collapsible lattice frame for the walls belonged to the first millennium AD and it was associated with the Türks (Weinstein 1976: 46; 1991: 50, 54-55; Kryukov, Malyavin, and Sofronov 1984: 140-143; Kryukov and Kurylev 
2000: 10-17). This may also be indirectly evidenced by the mention of the word käräkü which was recorded in the Bilgä Qaghan inscription (Şirin User 2009: 72-74), describing a lattice supporting a felt covering of a yurt (Clauson 1972: 744). The fact that the Türks' dwellings could be disassembled and transported can be indirectly gleaned from a passage of the Sui shū 隋書 about Shìwéi 室韋 tribes (Taskin 1984a: 136). At the same time, in certain forest-rich regions, as Leonid R. Kyzlassov tried to show, stationary octagonal wooden yurts were also used (Kyzlassov 1960: 66-67, 74; 1969: 46). This does not contradict the written sources on the presence of cattle in the herds of Türks (Bernshtam 1946: 41, 68, 71; Zuev 1967: 60, 72, 85).

Saul M. Abramzon, following up on the idea of a patriarchal community transforming into family-related units consisted of small families (Abramzon 1951; 1970: 64-69, 72-73; 1973: 297-303; 1990: 228, 453 [note 1]). He specifically examined the issue of the family forms among the Türks and agreed with Zuev's arguments, noting only that the processes described by him were characteristic of the earlier periods, while the 'autonomization' mentioned by Zuev should be properly understood as a disintegration of the patriarchal family and formation of familyrelated groups. Abramzon disagreed with Zuev's both opinions that the community transformed into patronymy, and that patronymy was the necessary form of community if small families were the basic roaming unit (Abramzon 1973: 301). Abramzon concluded that the conversion from the old lifestyle with dominant large family-communities to the new one in the middle of the first millennium $\mathrm{AD}$, meant a gradual strengthening of the small family (Ibid.: 303-304).

However, in his later works Zuev would change his mind. As early as 1998, he translated the above-mentioned fragment of Tōng Diăn 通典 similar to the translation of Taskin (Zuev 1998: 155; 2002: 289). ${ }^{3}$ He noted that the translation of the symbol jia 家 meaning a small unit like 'family' was excluded, because that symbol was often used in a figurative sense, describing, for example, peoples belonging to one state. At the same time, the yi kèhán 遺可汗 was elevated to the same position as yabru (Ibid:: 159; 2002: 290). Zuev based this interpretation on data from Abū'l-Ğàzī, translating an Arabic sentence as 'there is a ruler (törä) in each $i l$,' and wrote: 'Turks characterize such state as "at the head of the house is the black khan" (öy bašïa qara han) meaning in every house a common man becomes a khan, each house has its own khan' (Kononov 1958: 48 and 68). Therefore, Zuev considered the title yí kèhán 遺可汗 unrelated both to the room, and the monogamous family, and the patriarchal family, but as it was 'at the dawn of the Turks history' the title of 
a domain (udel) ruler (Zuev 1998: 160). ${ }^{4}$ However, in his last fundamental work the scholar definitely talked about the patriarchal family with surviving elements of maternal clans based on the collective ownership of land and the means of production, alongside matrilocal marriage (Idem 2002: 167-168).

Similar interpretations can be found in Chinese historiography. In particular, Cài Hóngshēng 蔡鸿生 argued that the patriarchal family had been 'the smallest economic unit of Türkic nomadic society in the sixth eigth centuries,' based on the use of the terms zhàng 帳 'tent' and hù F 'household,' 'family' in the sources related to the Türks and Chinese people, respectively (cited in Zuev 1967: 79). Lín Gàn 林干 considered the Türk family as part of a scheme according to which Türk society was a transient stage between a primitive and a slave society (Lin Gan 2000: 362-363).

According to Ecsedy Ildikó, the smallest economic unit of the Türks was the extended family, denoted in Chinese sources by the term zhàng 帳 'tent' (Ecsedy 1972: 251). Several other researhers agreed with similar interpretation (Clauson 1962: 11; Krader 1963: 185; Kwanten 1979: 4243). Omeljan Pritsak estimated the number of people in one household to be around 5-7 people (Pritsak 1983: 360). Louis Bazin, however, described that the unit of Turco-Mongol nomads as 'famille étendue, de type patriarchal' (Bazin 2000: 1104).

There has been some debate on this topic in Turkish historiography. Sadri Maksudi (Arsal), the author of a prominent work on Turks law considered the traditional Turks family as patriarchal (Maksudi Arsal 2002: 270). Abdülkâdir İnan drew attention to the high status of women in the social life of the Türks, and the fact that qayans and yabyu had their own quarters leading to the conclusion that the patriarchal family (ataerki (pederşahi) aile) was the dominant unit among the Türks. At the same time, there were tribes that had maintained their 'ancient customs' (ilkel âdetleri). This was mainly caused by their living environments (İnan 1948: 136-137). Working in Turkey, Hungarian scholar Rásonyi László also believed that the basic unit of Turks nomadic society was the monogamous large patriarchal family (Rásonyi 1971: 56-57). Meanwhile, İbrahim Kafesoğlu, in his seminal work, furthered the novel idea that only a small family close to the extended one had existed among the Turks nomads because it would be impossible for a large family to exist under the conditions of a nomadic economy (Kafesoğlu 1997: 220).

The idea of a large family can be found in the work of Doğan Avcioğlu (Avcioğlu 1978: 235). Mahmut Arslan drew attention to the importance of the principle of collective kinship, taking into consideration the results of both Maksudi (Arsal) and Kafesoğlu in his analysis of the 
family institutions of the nomadic Turks, in an attempt to combine both of these ideas. He described a large family (geniş aile) headed by a householder (Pater familia), which existed de jure (hukuken) only, and included a number of small families. Therefore, Arslan offered rejecting of the definition of 'small family' (küçük aile) in the case of the nomads (Arslan 1984: 37-38). The importance of this work lies only in its demonstration of the lack of argumentation in the expressed declaratively ideas of Kafesoğlu. Nevertheless, the constructions of Arslan himself were speculative.

Later on the thought of Kafesoğlu was accepted by a significant number of researchers (Donuk 1982; Taşağ1l 2003b, etc.).

At present, most scholars believe that it is the nuclear family of four, five, or sometimes six to eight members that forms the elementary taxonomic unit of nomadic society (Khazanov 1975: 73-76; 2002: 227-231; Shalkhakov 1983; Tortika, Mikheev, and Kortiev 1994: 54; etc.), in particular, of the Türks (Türkdoğan 1992: 29; Güler 1992: 62; Eröz and Güler 1998: 49-50; Zhumaganbetov 2003: 126, 331; Batsüren 2009: 166) and Yenisei Qïrqïz (Ugdyzhekov 2000: 14-15).

Meanwhile, the adherents of the Marxist approach still exist. In particular, Dmitry G. Savinov in his studies of the ancient Turks family in general, referred to Yenisei runic epitaphs while arguing that a 'large undivided (patriarchal) family was generally characteristic of nomadic societies' (Savinov 2013: 282).

However, the following facts evidence in favor of the dominance of the nuclear family among the Türks.

Firstly, as Zuev noted, a passage of the Xīn Táng shū 新唐書 described the son of Tài-zōng 太宗. He was fond of the Türks' lifestyle and organized games with his comrades, in which he ordered a group of five people to form a 'horde' of one tent (qióng-lú 穹盧) denoted in the source with the symbol luò 落 (Zuev 1967: 78-79; see Liu Mau-Tsai 1958: 283). In the early Chinese sources the symbol luò 落 marked a 'tent' in descriptions of nomadic people, while the Chinese family had been denoted by the symbol hù 戶 'household' (Duman 1970: 45 (note 25); Taskin 1984b: 15). ${ }^{5}$ Lyudmila A. Borovkova considered that luo 落 consisted of 'only five people' (Borovkova 1992: 67, 168 (note 1)). According to the Zhōu $s h \bar{u}$ 周書, the Tiě-lè 鐵勒 people, when the Türkic qayan invaded them in 546 , were in a number of 50 thousand tents (luò 落) (Borovkova 1992: 94). In the corresponding fragment in Suí shū 隋書 and Běi shř 北史 the symbol jiā 家 is used. ${ }^{6}$ The latter means 'a family', 'a household', 'a 
dynasty', etc. (Oshanin 1984: 840). Secondly, approximately the same number of members of families can be calculated from statistical data on the nomadic subjects of the Táng 唐 Empire. For the Türks and other steppe families included in Jiù Táng shū 舊唐書 the average calculated number is 4.22 people, while for the tribes inhabiting the Altai territory, it is 7.5 people (Zuev 1967: 81-82).

Therefore we can find no reason to assume that the basic Türkic family unit was a large one, rather than a standard nuclear one. However, there is another question - that of the nomadic polygamy.

It should be noted that there is no direct evidence of this phenomenon among the Türks in written sources. It was Bernshtam who furthered the original idea that nomad wives were allocated to different yurts, each associated with independent camp (Bernshtam 1946: 94). This phenomenon is known not only among the Mongols, but, for example, also among the Kazakhs (Andreev 1998: 64; Levshin 1996: 338) and Altaians (Dyrenkova 1926: 255). Bernshtam believed this practice reflected the territorial distribution of general patriarchal household of a clan (originally: rod) to the number of family households, each of which was headed by a woman who managed them indirectly for the head of the clan (rod) (Bernshtam 1946: 94-98). Therefore, each of the yurts was a small unit of the common household owned by one man, being the head of a clan. The phenomenon was of extreme practical importance in light of the instability of the nomadic economy. The distribution of livestock across different sections of a family's economic territory facilitated the care of large numbers of livestock ( $c f$. Tolybekov 1971: 536) and, additionally, increased the chances of saving livestock in the case of local disasters ( $c f$. Potapov 1975: 123).

Therefore, the term ayil, mentioned in the Suji inscription (line 5) should be translated neither as 'a tent', 'cote', nor as 'a pinfold' etc., but as 'a camp', or 'a settlement' like the Mongolian ayil (Klyashtorny 1959: 163; Pritsak 1981: 13). The memoriant of the Inscription was proud of both the ten 'settlements' (ayil), being interpreted as quarters or camps, and a number of livestock yilqï (Suji Inscription, line 5). It is possible the term should be interpreted similarly in the passage of Ïrq Bitig (fr. 47), which contains the phrase ayilïgta yïlqüy bolzun ('Let there be livestock in your quarter!').

The word $\ddot{a} b$ was used in Old Turks runic writing monuments with a wide range of meanings (Tuna 1988: 66-67), primarily in the sense of 'tent', or 'house' (Clauson 1972: 3-4). The Suji Inscription (line 6)

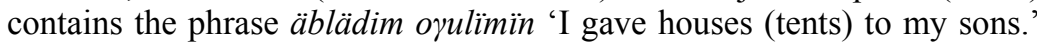
Recent debate focuses on the interpretation of the second lexeme as bayladïm (continuing the phrase on the next line). This, however, only revises the understanding of the action object. Following this, the daughters of the 
memoriant received tents (Şirin User 2009: 110-111). The existence of phrases containing the word $\ddot{a} b$ in the Mogoin Šine Usu Inscription in three different fragments in a row (Eastern side, lines 29, 30, 31) clearly demonstrates that the word means both the stationary stands in general and those of individual families, or even the movable households (Tuna 1988: 66; Klyashtorny 2010: 57, 64-65). Therefore, it is clear that the word $\ddot{a} b$ denoted the smallest economic unit of a nomadic society, being a tent or yurt, i.e. one household (cf. Gabain 1949: 38; Ögel 1971: 133). ${ }^{8}$

In relation to this issue, we like to point to the term qunčuy 'wife' in the Yenisei inscriptions, which in some cases was preceded by the word quy-da (Kormushin 2008: 258-261), i.e. 'in the house." The term quy originated from the Chinese gui 閏 'women apartment' (Clauson 1972: 674). Tuncer Baykara argued that quy were stationary stands (Baykara 1995: 25-26, 28-29). In epitaphs the word qunčuy often precedes the word o zul 'children, sons' in the common syntactic structure (Kormushin 2008: 261-262). For instance, in the Öök Turan Inscription (Ye 3, line 1) qujda qunčuj-ïm preceded to öz-dä ovlï-m, meaning in that context 'my own sons.' Osman Fikri Sertkaya and Igor V. Kormushin linked the determinative $\ddot{o z d a ̈ ~ t o ~ t h e ~ g r o u p ~ t h a t ~ i n c l u d e s ~ q u n c ̌ u y ~ a n d ~ d e t e r m i n a t i v e ~}$ quyda, having noticed that $\ddot{o} z$ oyli had been denoted as offspring of the quyda qunčuy (Sertkaya 1995: 71; Kormushin 1997: 193-194; cf. Bernshtam 1946: 92).

Some epitaphs also mention the word äbč (Kormushin 1997: 146; 2008: 263-264). In the Bayan Köl Inscription we find the combination $\ddot{o z}$ äbči qunčuy-ïmqa (Ye 100, line 1), this being the only case where these words have been found together (Kormushin 1997: 252) giving reason to assume the Turks word $\ddot{a} b$ replaced the Chinese synomym quy. As Kormushin believes, being derivative from the word $\ddot{a} b$ the term $\ddot{a} b \check{c} i$ eventually acquired a new meaning, transforming from determinative to objective: 'housewife', 'housekeeper' > 'wife' > 'woman' in general (Kormushin 2008: 263).

These data can be correlated with the ethnographically registered nomadic custom of including a tent in a dowry (Andreev 1998: 62-63; Levshin 1996: 335, 338; Grodekov 1889: 47). The Kazakhs, meanwhile had a practice of allocating a widow a tent if she did not want to marry again and preferred to stay with her father (Grodekov 1889: 52-53).

A description of the Turks custom of contributing one's daughter for the injury of somebody's eye can be found in Chinese sources. If one had no daughter one ought to contribute some of his wife's property. The Suí

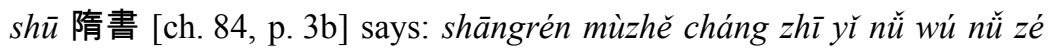
$s h \bar{u}$ fù cái 傷人目者償之以女無女則 輸婦財. Evgeny I. Kychanov believed the Türks equated women with property because they 'went to pay 
for some criminal offenses,' He based this opinion on his interpretation of the phrase fù cái 婦財 as 'wife and property' (Kychanov 2010: 131), though he did not dispute Nikita Ya. Bichurin's translation of 'wife's property' (Bichurin 1950: 230). Several variants have been offered by other scholars: 'sa propre femme' (Visdelou 1779: 127), 'femme et ses richesses' (Julien 1864: 352), 'wife or the other property' (Parker 1900: 166, 171), 'seine Frau und seine Vermögen' (Liu Mau-Tsai 1958: 42), 'bir äyeldiñ qunyn töledi' (Ezhenkhanuly and Ozhan 2006: 67) and the most original, based on the Tōng Diăn 通典 (ch. 197, here the symbol cái 財 is absent) 'kadınla veya kadınsız karşılığını öder' (Taşağıl 2003a: 98 and a Chinese text in s. 200). The symbol fú 婦 '(married) woman', 'wife' can be considered as a grammatically unformed attributive of the word cái 財 'wealth', 'property', and in such case the functional word $z h \bar{\imath}$ 之 lost. The phenomenon mentioned has been known since the Late Old Chinese period (Yakhontov 1965: 104; Sofronov 2007: 180). These arguments give additional reason to assume that a tent was a part of a dowry.

There is no room in this article to analyze other aspects of family institution (the institution of kalym, elements of matrilocality, the legal status of wives and captured women, inheritance systems, etc.) although there is a need for these. However, the data presented here provides convincing evidence in favor of the nuclear type of Türks family, and the exceptional practical nature of the phenomenon of polygamy.

\section{NOTES}

* This study has been supported by the mega-grant of the Government of Russian Federation (\# № 14.W03.31.0016) 'Dynamics of peoples and empires in Inner Asia.'

${ }^{1}$ The orthographic form Türk is used in the paper to describe the tribal group that dominated Inner Asia during the period from the second half of the sixth century to the first half of the eighth century AD. At the same time, the definition Ancient Turks is used for the description of all Turkic-speaking people that lived in the region during the defined period, while their language is denoted by a common term Old Turks. The word Turk / Turkic describes all of the peoples of the linguistic group.

${ }^{2}$ Edwin G. Pulleyblank, assuming that this designation could be the borrowing of a foreign word, admited that its Early Han transcription being khiun-lio indicated it is a Turks origin more than a Mongolian one. However, it is impossible to say anything concrete (Pulleyblank 1986: 32).

${ }^{3}$ Also compare his later translation in Zuev 2002: 212.

${ }^{4} C f$. in the work of Claude Visdelou: 'Ils donnoient quelquefois le titre de Khan aux Lieutenans des Che-hou, Ils appelloient aufli par honneur les Chefs des grandes familles Ouei-khan, ou Khan de maifon, car Ouei ou $\mathrm{Yi}$ dans cette Langue, fignifioit maifon, ou famille' (Visdelou 1779: 126).

Also compare the translation of Ahmet Taşağıl based on the Tōng diăn 通典, which mistakenly considered the expression 'Onun altında Ye-hu (Yabgu) vardır' in conjuction 
with the previously described title fullin kèhán 附鄰可汗. He then wrote: 'Bazen belirli bir yerde ikâmet eden ailelerin büyük soyadlıları, karşıklı olarak kendi içlerinden kagan seçerlerdi. Gök-Türkler, onu İ-yen-wu diye çağıırıllar' (Taşağıl 2003a: 97).

Here is also his translation of similar passage from the Cè fù yuán gū̄ 冊府元龜:

'Kaganlığın altında yabguluk vardır. Ya da ikâmet eden ailelerin büyük soyadlıları kendilerinin İ Kağan ilân ederler.

Gök-Türkler buna İ-yen-wu Kagan derler' (Taşağıl 2003a: 114).

${ }^{5} C f$ : : this word is loosely used, but it evidently means a tent, with the animals, \&c., belonging to it' (Parker 1899: 121, 126 note 26).

${ }^{6}$ In the other place of Běi shĭ 北史 it is also luò 落 (Parker 1900: 163, 164, 168 note 80, 171). For the different translation of those fragments see Bichurin 1828: 110; Julien 1864: 350; Parker 1900: 163, 171 (first mention in Běi shǐ 北史); Liu Mau-Tsai 1958: 7 (Anm. 25); Ezhenkhanuly and Ozhan 2006: 66.

${ }^{7}$ Cf. variants of the translation Zhōu shü 周書 and Bě̀ shǐ 北史 in Julien 1864: 329; Parker 1899: 121, 126 (note 26); 1900: 164; Liu Mau-Tsai 1958, 7, 492 (Anm. 25); Taşağıl 2003a: 17; Ezhenkhanuly and Ozhan 2006: 121; Kara 2015: 548 (dipnot 37)

${ }^{8}$ The remarkable fact is that Stanislav A. Ugdyzhekov came to a similar conclusion basing on the data on Yenisei Qirqïz (Ugdyzhekov 2000: 15).

9 Bernshtam interpreted the combination quyda qunčuy as 'harem' (Bernshtam 1946: 50). According to Ugdyzhekov, there were noble women 'having an opportunity to have special women's apartments' (Ugdyzhekov 2000: 17).

\section{REFERENCES}

Abramzon, S. M. 1951. The Forms of Tribal Organization among the Nomads of Central Asia. In Tolstov, S. P. (ed.), Clan Society. Ethnographic Materials and Research (pp. 132-156). Moscow: Nauka. Original in Russian (Абрамзон, C. М. Формы родоплеменной организации у кочевников Средней Азии. В: Толстов, С. П. (ред.), Родовое общество. Этнографические материалы и исследования, с. 132-156. М.: АН СССР).

Abramzon, S. M. 1970. Some Problems of Social System of Nomadic Societies. Sovetskaya etnografiya 6: 61-73. Original in Russian (Абрамзон, С. М. Некоторые вопросы социального строя кочевых обществ. Советская этнография 6: 61-73).

Abramzon, S. M. 1973. The Forms of a Family in the Pre-Turkic and Turkic Tribes of Southern Siberia, Semirechye and Tien Shan in Antiquity and the Middle Ages. In Kononov, A. N., Klyashtorny, S. G., Petrosian, Yu. A., and Tselniker, S. S. (eds.), The Works in Turcic Studies, 1972 (pp. 287-305). Moscow: Nauka. Original in Russian (Абрамзон, С. М. Формы семьи у дотюркских и тюркских племен Южной Сибири, Семиречья и Тянь-Шаня в древности и средневековье. В: Кононов, А. Н., Кляшторный, С. Г., Петросян, Ю. А., Цельникер, С. С. (ред.), Тюркологический сборник 1972, с. 287-305. М.: Наука).

Abramzon, S. M. 1990. Kirghiz and Their Ethnogenetic and Historical-Cultural Ties. Frunze: Kyrgyzstan. Original in Russian (Абрамзон, С. М. Киргизы и их этногенетические и историко-культурные связи. Фрунзе: Кыргызстан). 
Andreev, I. G. 1998. The Description of the Middle Horde of the Kirgiz-Kaisaks. Almaty: Ghylym. Original in Russian (Андреев, И. Г. Описание средней орды киргиз-кайсаков. Алматы: Гылым).

Arslan, M. 1984. Social and Political Organization of Steppe Empires. Istanbul: University Faculty of Literature Printing House. In Turkish (Arslan, M. Step Imparatorluklarında Sosyal ve Siyasî Yapı. İstanbul: Üniversitesi Edebiyat Fakültesi Basimevi).

Avcioğlu, D. 1978. A History of Turks. Vol. 1. Istanbul: Tekin Publishing House. In Turkish (Avcıoğlu, D. Türklerin Tarihi. Cilt 1. İstanbul: Tekin Yayınevı).

Batsüren, B. 2009. High Chariots and Ancient Turks (the $6^{\text {th }}-$ the $9^{\text {th }}$ Centuries). Ulaanbaatar: Möhkhiin Useg. Original in Mongol (Батсүрэн, Б. Өндөр тэрэгтнүүд ба эртний түрэгүYд (VI-IX зуун). Улаанбаатар: Мөнхийн үсэг).

Baykara, T. 1995. The Place of Göktürk Inscriptions in History of Turkic Settlement. Türk Dili Araştırmaları Yıllığı, Belleten 1990 (pp. 17-29). Ankara. In Turkish (Baykara, T. Göktürk Yazıtlarının Türk İskan (Yerleşme) Tarihindeki Yeri. Türk Dili Araştırmaları Yıllı̆̆ , Belleten 1990 (s. 17-29). Ankara).

Bazin, L. 2000. Les peuples turcs et mongols de la steppe: le nomadisme pastoral. In Al-Bakhit, M. A., Bazin, L. and Cissoko, S. M. (eds.), History of Humanity IV (pp. 1099-1111). Paris: Éditions UNESCO.

Bernshtam, A. N. 1946. Socio-Economic System of the Orhon-Yenisei Turks in the $6^{\text {th }}-8^{\text {th }}$ Centuries. Eastern Turkic Qaghanate and Kyrghyz. Moscow - Leningrad: Academy of Sciences of SSSR Press. Original in Russian (Бернштам, A. H. Сочиально-экономический строй орхоно-енисейских тюрок VI-VIII вв. Восточно-тюркский каганат и кыргызы. М.; Л.: Изд-во АН СССР).

Bichurin, N. Ya. (Hyacinth) 1928. The Notes on Mongolia. Vol. 2. Pt. 3-4. St. Petersburg: Karl Kray's Typography. Original in Russian (Бичурин, Н. Я. (Иакинф). Записки о Монголии. Т. II. Ч. 3-4. СПб.: Тип. Карла Крайя).

Bichurin, N. Ya. [Hyacinth] 1950. The Collection of Information about the Peoples Who Lived in Central Asia in Ancient Times. Vol. 1. Moscow - Leningrad: Academy of Sciences of SSSR Press. Original in Russian (Бичурин, Н. Я. [Иакинф]. Собрание сведений о народах, обитавщих в Средней Азии в древние времена. Т. 1. М. - Л.: Изд-во АН СССР).

Borovkova, L. A. 1992. The Problem of the Location of the Kingdom of Gaochang (According to Chinese Sources). Moscow: Nauka. Original in Russian (Боровкова, Л. А. Проблема местоположения царства Гаочан (по китайским источникам). М.: Наука).

Clauson, G. 1962. Türkish and Mongolian Studies. London: Royal Asiatic Society.

Clauson, G. 1972. An Etymological Dictionary of Pre-Thirteenth-Century Turkish. Oxford: Clarendon Press.

Donuk, A. 1982. Family in Various Communities and in Old Turkic One. Tarih Dergisi 33: 147-168. In Turkish (Donuk, A. Çeşitli Topluluklarda ve Eski Türkler'de Âile. Tarih Dergisi 33: 147-168).

Drompp, M. R. 1991. Supernumerary Sovereigns: Superfluity and Mutability in the Elite Power Structure of the Early Türks (Tujue). In Seaman, G., and Marks, D. (eds.), Rulers from the Steppe: State Formation on the Eurasian 
Periphery (pp. 92-115, 350-352). Los Angeles: University of Southern California Ethnographics Press.

Duman, L. I. 1970. Foreign Relations of China with the Xiongnu in the $1^{\text {st }}$ $3^{\text {rd }}$ Centuries. In Tikhvinskiy, S. L., and Perelomov, L. V. (eds.), China and Its Neighbors in Antiquity and Middle Ages (pp. 37-50). Moscow: Nauka. Original in Russian (Думан, Л. И. Внешнеполитические связи Китая с сюнну в I-III вв. В: Тихвинский, С. Л., Переломов, Л. В. (ред.), Китай и соседи в древности и средневековье, с. 37-50. М.: Наука).

Dyrenkova, N. P. 1926. Genus, Classification System of Kinship and Marriage Traditions Among the Altai and Teleut People. In Bogoraz, V. G., and Shternberg, L. Ya (eds.), The Materials on the Wedding and Family-Tribal System of the Peoples of the USSR. Vol. 1 (pp. 247-259). Leningrad: Student Ethnographic Tour Commission Press. Original in Russian (Дыренкова, Н. П. Род, классификационная система родства и брачные нормы у алтайцев и телеут. В: Богораз, В. Г., Штернберг, Л. Я. (ред.), Материаль по свадьбе и семейно-родовому строю народов СССР. Вып. 1, с. 247-259. Л.: Издание Комиссии по устройству студенческих этнографических экскурсий).

Ecsedy, H. 1972. Tribe and Tribal Society in the $6^{\text {th }}$ Century Turk Empire. Acta Orientalia Academiae Scientiarum Hungaricae 25: 245-262.

Ezhenkhanuly, B., and Ozhan, Zh. (trans.) 2006. Chinese Sources on the History of Kazakhstan. Historical Chronicles. Vol. 4. Almaty: Daik-Press. Original in Kazakh (Еженханұлы, Б., Ожан, Ж. Қазақстан тарихы туралы қытай деректемелері. Эулеттік тарихи жылнамалар, Т. 4. Алматы: Дайк-Пресс).

Eröz, M., and Güler, A. 1998. Turkic Family. Ankara: Atatürk Supreme Council for Culture, Language and History. In Turkish (Eröz, M., and Güler, A. Türk Ailesi. Ankara: AYK Atatürk Kültür Merkezi Başkanlığı).

Gabain, A. von 1949. Steppe und Stadt im Leben der ältesten Türken. Der Islam 29 (1): $30-62$.

Grodekov, N. I. 1889. The Kirgiz and Kara-Kirgiz of the the Syr Darya Region. Legal Norms. Vol. 1. Tashkent: S. I. Lakhtin's Press. Original in Russian (Гродеков, Н. И. Киргизы и каракиргизы Сыр-Дарьинской области. Юридический быт. Т. 1. Ташкент: Типо-лит. С. И. Лахтина).

Gumilev, L. N. 1967. Ancient Türks. Moscow: Nauka. Original in Russian (Гумилев, Л. Н. Древние тюрки. М.: Наука).

Güler, A. 1992. Family and Its Features in the First Written Turkic Texts. In Y1ldı, H. D. (ed.), Turkish Family in the Process of Socio-Cultural Change. Vol. 1 (pp. 60-72). Ankara: Atatürk Supreme Council for Culture, Language and History. In Turkish (Güler, A. İlk Yazılı Türkçe Metinlerde Ail eve Unsurları. In Yıldız, H. D. (ed.), Sosyo-Kültürel Değişme Sürecinde Türk Ailesi. Vol.1 (pp. 60-72). Ankara: Atatürk Kültür, Dil ve Tarih Yüksek Kurumu Atatürk Kültür Merkezi Başkanlığı).

Julien, S. 1864. Documents historiques surles Tou-kiue (Turcs). Extraits du Pieni-tien et traduits du chinois. Journal Asiatique 6 (3): 325-367, 491-549.

İnan, A. 1948. Traditions Related to Institution of Adoption in Nomadic Turkic Tribes. Ankara Üniversitesi Dil ve Tarih-Coğrafya Fakültesi Dergisi 6 (3): 
127-137. In Turkish (İnan, A. Göçebe Türk Boylarında Evlâtlık Müesseseleriyle İlgili Gelenekler. Ankara Üniversitesi Dil ve Tarih-Coğrafya Fakültesi Dergisi 6 (3): 127-137).

Kafesoğlu, İ. 1997. Turkic National Culture. Istanbul: Ötüken Publ. In Turkish (Kafesoğlu, İ. Türk Milli Kültürü. Istanbul: Ötüken Neşriyat).

Kara, G. 2015. An Analysis of the Chapter on Turks in the History of Zhou. Insan ve Toplum Bilimleri Araştırmaları Dergisi 4 (3): 542-562. In Turkish (Kara, G. Zhou Tarihi'nin Türkler Bölümü Üzerinde Metin Çalışması. İnsan ve Toplum Bilimleri Araştırmaları Dergisi 4 (3): 542-562).

Khazanov, A. M. 1975. The Social History of the Scythians. Main Problems of the Development of the Ancient Nomads of the Eurasian Steppes. Moscow: Nauka. Original in Russian (Хазанов, А. М. Социальная история скифов. Основные проблемы развития древних кочевников евразийских степей. М.: Наука).

Khazanov, A. M. 2002. Nomads and Outside World. Almaty: Daik-Press. Original in Russian (Хазанов, А. М. Кочевники и внешний мир. Алматы: ДайкПресc).

Klyashtorny, S. G. 1959. The Historical and Cultural Importance of the Suji Inscription. Problemy vostokovedeniya 5: 162-169. Original in Russian (Кляшторный, С. Г. Историко-культурное значение Суджинской надписи. Проблемы востоковедения 5: 162-169).

Klyashtorny, S. G. 2003. The History of Central Asia and Monuments of Runic Writing. St. Petersburg: St.-Petersburg State University, Faculty of Philology. Original in Russian (Кляшторный, С. Г. История Центральной Азии u памятники рунического письма. СПб.: Филологический факультет СПбГУ).

Klyashtorny, S. G. 2010. Runic Monuments of the Uighur Qaghanate and History of Eurasian Steppes. St. Petersburg: Peterburgskoye vostokovedeniye. Original in Russian (Кляшторный, С. Г. Рунические памятники Уйгурского каганата и история евразийских степей. СПб.: Петербургское востоковедение).

Kononov, A. N. 1958. Genealogy of Turkmen. Composition of Abu'l-Ghazi, Khan of Khiva: Analysis, Text, Translation. Moscow - Leningrad: Academy of Sciences of SSSR. Original in Russian (Кононов, А. Н. Родословная туркмен. Сочинение Абу-л-гази, хана хивинского: [Исследование, тексты, перево$\partial b l]$. М. - Л.: Изд-во АН СССР).

Kormushin, I. V. 1997. Turkic Yenisei Epitaphs. Texts and Analysis. Moscow: Nauka. Original in Russian (Кормушин, И. В. Тюркские енисейские эпитафии. Тексты и исследования. М.: Наука).

Kormushin, I. V. 2008. Turkic Yenisei Epitaphs: Grammar, Text Analysis. Moscow: Nauka. Original in Russian (Кормушин, И. В. Тюркские енисейские эпитафии: грамматика, текстология. М.: Наука).

Krader, L. 1963. Social Organization of the Mongol-Turks Pastoral Nomads. The Hague: Mouton \& Co.

Kryukov, M. V. 1988. East Turkestan in the $3^{\text {rd }}$ century B.C. - the $6^{\text {th }}$ Century A.D. In Tikhvinskiy, S. L. and Litvinskiy, B. A. (eds.), East Turkestan in An- 
tiquity and the Early Middle Ages: Essays on History (pp. 223-296). Moscow: Nauka. Original in Russian (Крюков, М. В. Восточный Туркестан в III в. до н. э. -6 в. н. э. В: Тихвинский, С. Л., Литвинский, Б. А. (ред.), Восточный Туркестан в древности и раннем средневековье: очерки истории, с. 223-296. М.: Наука).

Kryukov, M. V., and Kurylev, V. P. 2000. Toward the Early History of the Yurt (According to Chinese Sources of the $3^{\text {rd }}$ Century B.C. - the $13^{\text {th }}$ Century A.D.). In Vassilyeva, G. P. (ed.), Nomadic Dwelling of the Peoples of Central Asia and Kazakhstan (pp. 10-19). Moscow: Nauka. Original in Russian (Крюков, М. В., Курылев, В. П. К ранней истории юрты (по китайским источникам III в. до н. э. - ХІІІ в. н. э.). В: Васильева, Г. П. (ред.), Кочевое жилище народов Средней Азии и Казахстана, с. 10-19. М.: Наука).

Kryukov, M. V., Malyavin, V. V., and Sofronov, M. V. 1979. Chinese Ethnos in Anticipation of the Middle Ages. Moscow: Nauka. Original in Russian (Крюков, М. В., Малявин, В. В., Софронов, М. В. Китайский этнос на пороге средних веков. М.: Наука).

Kwanten, L. 1979. Imperial Nomads: A History of Central Asia, 500-1500. Philadelphia: University of Pennsylvania Press.

Kyuner, N. V. 1961. Chinese Data on the Peoples of South Siberia, Central Asia and the Far East. Moscow: Nauka. Original in Russian (Кюнер, Н. В. Kuтайские известия о народах Южной Сибири, Центральной Азии и Дальнего Востока. М.: Наука).

Kyzlassov, L. R. 1960. Tuva during the Period of the Turkic Qaghanate (the $6^{\text {th }}-$ the $8^{\text {th }}$ Centuries). Vestnik Moskovskogo Gosudarstvennogo Universiteta Ser. 9. Historical Sciences 1: 51-78. Original in Russian (Кызласов, Л. Р. Тува в период Тюркского каганата (VI-VIII вв.). Вестник МГУ. Сер. IX Исторические науки 1: 51-78).

Kyzlassov, L. R. 1969. A History of Tuva in the Middle Ages. Moscow: Moscow State University. Original in Russian (Кызласов, Л. Р. История Tувы в средние века. М.: МГУ).

Kychanov, E. I. 2010. The History of Ancient and Medieval States Bordering China (from the Huns to the Manchu). St. Petersburg: Peterburg Linguistic Society. Original in Russian (Кычанов, Е. И. История приграничных с Китаем древних и средневековых государств (от гуннов до маньчжуров). СПб.: Петербургское лингвистическое общество).

Lashuk, L. P. 1967. On the Nature of Class-formation in Early Nomad Societies. Voprosy istorii 7: 105-121. Original in Russian (Лашук, Л. П. О характере классообразования в обществах ранних кочевников. Вопросы истории 7: 105-121)

Levshin, A. I. 1996. Description of the Kirgiz-Kazak or Kirgiz-Kaisat Hordes and Steppes. Almaty: Gylym. Original in Russian (Левшин, А. И. Описание киргиз-казачьих или киргиз-кайсаџких орд и степей. Алматы: Санат).

Lin, Gan 2000. Göktürk Traditions and Religious Beliefs. Türk Dünyası Incelemeleri Dergisi 4: 361-374. In Turkish (Lin, Gan. Göktürklerde Gelenekler ve Dini İnançlar. Türk Dünyası İncelemeleri Dergisi 4: 361-374). 
Liu Mau-Tsai 1958. Die chinesischen Nachrichten zur Geschichte der Ost-Türken (T'u-küe). I-II. Buch. Wiesbaden: Otto Harrassowitz.

Maksudi Arsal, S. 2002. Turkic History and Law. Kazan: Fen. Original in Russian (Максуди Арсал, С. Тюркская история и право. Казань: Фэн).

Malyavkin, A. G. 1980. Tactics of the Tang State in the Struggle for Hegemony in the Eastern Part of Central Asia. In Derevianko, E. I. (ed.), The Far East and Neighboring Territories in the Middle Ages (pp. 103-126). Novosibirsk: Nauka. Original in Russian (Малявкин, А. Г. Тактика Танского государства в борьбе за гегемонию в восточной части Центральной Азии. В: Деревянко, Е. И. (ред.), Дальний Восток и соседние территории в средние века, с. 103-126. Новосибирск: Наука).

Malyavkin, A. G. 1981. The Historical Geography of Central Asia (Sources and Analysis). Novosibirsk: Nauka. Original in Russian (Малявкин, А. Г. Историческая география Центральной Азии (материаль и исследования). Новосибирск: Наука).

Markov, G. E. 1976. Nomads of Asia. The Structure of the Economy and Social Organization. Moscow: MGU. Original in Russian (Марков, Г. Е. Кочевники Азии. Структура хозяйства и общественной организации. М.: Изд-во МГУ).

Oshanin, I. M. (ed.) 1984. Large Sino-Russian Dictionary, Based on the Russian Graphic System. Vol. 3. Moscow: Nauka. Original in Russian (Ошанин, И. М. (ред.), Большой китайско-русский словарь по русской графической системе. Т. 3. М.: Наука).

Ögel, B. 1971. Ages of Development of Turkic Culture. Vol 2. Istanbul: National Education Printing House. In Turkish (Ögel, B. Türk Kültürünün Gelişme Çăgları. Cilt 2. İstanbul: Milli Eğitim Basımevi).

Parker, E. H. 1899. The Early Turks (From the CHOU SHU). The China Review 24 (3): 120-130.

Parker, E. H. 1900. The Early Turks (From the PEI SHI and the SUI SHU). The China Review 24 (4): 163-173.

Potapov, L. P. 1975. On the Feudal Ownership of Pastures and Nomadic Lands Among Tuvans (the $18^{\text {th }}-$ Early $20^{\text {th }}$ Centuries). In Reshetov, A. M., and Taksami, Ch. M. (eds.), Social History of Peoples of Asia (pp. 115-125). Moscow: Nauka. Original in Russian (Потапов, Л. П. О феодальной собственности на пастбища и кочевья у тувинцев (XVIII - начало XX в.). В: Решетов, А. М., Таксами, Ч. М. (ред.), Сочиальная история народов Азии, с. 115-125. М.: Наука).

Pritsak, O. 1981. The Origin of Rus'. Old Scandinavian Sources Other than the Sagas. Vol. 1. Cambridge (Mass.): Harvard University Press.

Pritsak, O. 1983. The Slavs and the Avars. In Gli Slavi occidentali e meridionali nell'alto Medioevo, 15-21 aprile 1982. Vol. 1 (pp. 353-435). Spoleto: Presso la Sede del Centro.

Pulleyblank, E. G. 1986. Xiongnu Language. In Kononov, A. N. (ed.), Foreign Turcology. Old Turkic Languages and Literature. Vol. 1 (pp. 29-70). Moscow: Nauka. Original in Russian (Пуллиблэнк, Э. Дж. Язык сюнну. В: Ко- 
нонов, А. Н. (ред.) Зарубежная тюркология. Древние тюркские языки и литературы. Вып. 1, с. 29-70. М.: Наука).

Rásonyi, L. 1971. Turkishness in History. Ankara: Turkish Culture Research Institute Publications. In Turkish (Rásonyi, L. Tarihte Türklük. Ankara: Türk Kültürünü Araştırma Enstitüsü Yayınları).

Savinov, D. G. 2013. Historical and Cultural Significance of Ancient Turkic Rune Inscriptions (Epitaphs). Vestnik Tomskogo Gosudarstvennogo Universiteta. Istoriya 3 (23): 279-284. Original in Russian (Савинов, Д. Г. Историкокультурное значение древнетюркских рунических надписей-эпитафий. Вестник Томского государственного университета. История 3 (23): 279-284).

Sertkaya, O. F. 1995. Correction of Some Readings and Meanings in Publications on Yenisei Inscriptions, New Reading and Meaning Offers. Türk Dili Araştırmaları Yıllığı, Belleten 1993 (pp. 67-75). Ankara. In Turkish (Sertkaya, O. F. Yenisey Yazıtlarının Yayınlarındaki Bazı Okuma ve Anlamlandırmaların Düzeltilmesi, Yeni Okuma ve Anlamlandırma Teklifleri. Türk Dili Araştırmaları Yıllı̆̆ , Belleten 1993 (s. 67-75). Ankara).

Sevortian, E. V. 1974. Etymological Dictionary of Turkic Languages (Common Turkic and Inter-Turkic Vowels). Moscow: Nauka. Original in Russian (Ceвортян, Э. В. Этимологический словарь тюркских языков (Общетюркские и межтюркские основы на гласные). М.: Наука).

Shalkhakov, D. D. 1983. On the Problem of the Form and Structure of the Family Among the Turkic-Mongolian Nomadic Cattle-Breeding Peoples. In Zakharova, I. V., and Tomilov, N. A. (eds.), Ethnogenesis and Ethnic History of the Turkic Peoples of Siberia and Adjacent Territories (pp. 136-144). Omsk: Omsk State University Press. Original in Russian (Шалхаков, Д. Д. К вопросу о форме и структуре семьи у тюрко-монгольских кочевых скотоводческих народов. В: Захарова, И. В., Томилов, Н. А. (ред.), Этногенез и этническая история тюркских народов Сибири и сопредельных территорий, с. 136-144. Омск: Омский университет).

Sofronov, M. V. 2007. Chinese Language and Chinese Writing: Lecture Course. Moscow: AST: Vostok - Zapad. Original in Russian (Софронов, М. В. Китайский язык и китайская письменность: курс лекций. М.: АСТ: Восток - Запад).

Şirin User, H. 2009. Köktürk and Ötüken Uighur Khaganate Inscriptions. Vocabulary Review. Ankara: Kömen Editions. In Turkish (Şirin User, H. Köktürk ve Ötüken Uygur Kă̆anlı̆̆l Yazıtları. Söz Varlı̆̆ Incelemesi. Ankara: Kömen Yayınları).

Taskin, V. S. (trans.) 1984a. Materials on the History of the Ancient Nomadic Peoples of the Donghu Group. Moscow: Nauka. Original in Russian (Таскин, B. C. (пер.) Материаль по истории древних кочевых народов группь дунху. М.: Наука).

Taskin, V. S. 1984b. Introduction. An Importance of Chinese Sources in the Study of the Ancient History of the Mongols. In: Taskin 1984a, 3-62. Original in Russian (Таскин, В. С. Введение. Значение китайских источников в изучении древней истории монголов. Таскин 1984a: 3-62). 
Taşağıl, A. 2003a. Gök-Türks I. Ankara: Turkish Historical Society Press. In Turkish (Taşağıl, A. Gök-Türkler I. Ankara: Türk Tarih Kurumu).

Taşağıl, A. 2003b. Administrative and Social Structure of Gök-Türks. Bilim ve Ütopya Dergisi 104: 20-25. In Turkish (Taşağıl, A. Gök-Türkler'de İdari ve Sosyal Yap1. Bilim ve Ütopya Dergisi 104: 20-25).

Tolstov, S. P. 1938. Tyranny of Abrui (From the History of the Class Struggle in Sogdiana and the Turkic Qaghanate in the $2^{\text {nd }}$ Half of the $6^{\text {th }}$ Century AD). Istoricheskiye zapiski 3: 3-53. Original in Russian (Толстов, С. П. Тирания Абруя (Из истории классовой борьбы в Согдиане и тюркском каганате во второй половине VI в. н. э.). Исторические записки 3: 3-53).

Tolstov, S. P. 1948. Ancient Khorezm: An Experience of Historical and Archaeological Research. Moscow: Moscow State University Press. Original in Russian (Толстов, С. П. Древний Хорезм: Опыт историко-археологического исследования. М.: МГУ).

Tolybekov, S. E. 1971. Nomadic Society of Kazakhs in the $17^{\text {th }}-$ Early $20^{\text {th }}$ Century (Political and Economic Analysis). Alma-Ata: Nauka. Original in Russian (Толыбеков, С. Е. Кочевое общество казахов в XVII - начале XX века (Политико-экономический анализ). Алма-Ата: Наука).

Tortika, A. A., Mikheev, V. K, and Kortiev, R. I. 1994. Some EcologicalDemographic and Social Aspects of the History of Nomadic Societies. Etnograficheskoye obozreniye 1: 49-62. Original in Russian (Тортика, A. A., Михеев, В. К, Кортиев, Р. И. Некоторые эколого-демографические и социальные аспекты истории кочевых обществ. Этнографическое обозрение 1: 49-62).

Tuna, O. N. 1988. Some Orthographic Traditions and Their Importance in Text Analysis and a Few Explanations in Orkhon Inscriptions. Türk Dili Araştırmaları Ylllı̆̆ , Belleten 1957 (pp. 41-81). Ankara. In Turkish (Tuna, O. N. Bazı İmlâ Gelenekleri Bunların Metin İncelemelerindeki Önemi ve Orhon Yazıtları'nda Birkaç Açılklama. Türk Dili Araştırmaları Yıllı̆̆ı, Belleten 1957 (s. 41-81). Ankara).

Türkdoğan, O. 1992. General Structure of Turkic Family. In: Y1ldız, H. D. (ed.), Turkish Family in the Process of Socio-Cultural Change 1 (pp. 21-58). Ankara: Atatürk Supreme Council for Culture, Language and History. In Turkish (Türkdoğan, O. Türk Ailesinin Genel Yapısı. In: Yıldız, H. D. (ed.), SosyoKültürel Değişme Sürecinde Türk Ailesi 1 (s. 21-58). Ankara: Atatürk Kültür, Dil ve Tarih Yüksek Kurumu Atatürk Kültür Merkezi Başkanlığı).

Ugdyzhekov, S. A. 2000. Social Structure of Medieval Kirghiz: Cand. Hist. Sc. Dissertation. Thesis Abstract. Tomsk. Original in Russian (Угдыжеков, С. A Социальная структура раннесредневековых кыргызов: автореф. дис. ... канд. ист. наук. Томск).

Weinstein, S. I. 1976. The Problems of the History of a Dwelling of the Steppe Nomads of Eurasia. Sovetskaya etnografiya 4: 42-62. Original in Russian (Вайнштейн, С. И. Проблемы истории жилища степных кочевников Евразии. Советская этнография 4: 42-62).

Weinstein, S. I. 1991. A World of Nomads of Center of Asia. Moscow: Nauka. Original in Russian (Вайнштейн, С. И. Мир кочевников центра Азии. М.: Наука). 
Weinstein, S. I., and Kryukov, M. V. 1976. 'Li Ling's Palace,' or the End of One Legend. Sovetskaya etnografiya 3: 136-149. Original in Russian (Вайнштейн, С. И., Крюков, М. В. «Дворец Ли Лина», или конец одной легенды. Советская этнография 3: 136-149).

Visdelou, C. 1779. Histoire de la Tartarie. In d'Herbelot, B., Bibliothèque orientale. Vo. 4 (pp. 46-249). La Haye: J. Neaulme \& N. van Daalen.

Yakhontov, S. E. 1965. Old Chinese Language. Moscow: Nauka. Original in Russian (Яхонтов, С. Е. Древнекитайский язык. М.: Наука).

Zhumaganbetov, T. S. 2003. The Problems of Formation and Development of the Ancient Turkic System of Statehood and Law. The $6^{\text {th }}-$ the $12^{\text {th }}$ Centuries. Almaty: Zheti zharghy. Original in Russian (Жумаганбетов, Т. С. Проблемы формирования и развития древнетюркской системы государственности и права. VI-XII вв. Алматы: Жеті жарғы).

Zuev, Yu. A. 1967. Ancient Turkic Genealogical Legends as a Source on the Early History of the Turks: Cand. Hist. Sc. Dissertation. Alma-Ata. Original in Russian (Зуев, Ю. А. Древнетюркские генеалогические предания как источник по ранней истории тюрков: дис. ... канд. ист. наук. Алма-Ата).

Zuev, Yu. A. 1977. Western-Turkic Qaghanate. In Akishev, K. A., Baipakov, K. M., Kadyrbaev, M. K., and Kumekov, B. E. (eds.), The History of the Kazakh Socialist Republic. From Ancient Times to the Present Days. Vol. 1 (pp. 321-336). Alma-Ata: Nauka. Original in Russian (Зуев, Ю. А. Западно-тюркский каганат. В: Акишев, К. А., Байпаков, К. М., Кадырбаев, М. К., Кумеков, Б. Е. (ред.), История Казахской ССР. С древнейших времен до наших дней. Том 1 , c. 321-336. Алма-Ата: Наука).

Zuev, Yu. A. 1998. Old Turkic Social Terminology in the Chinese Text of the $8^{\text {th }}$ Century. In Samashev, Z. (ed.), Problems of Archaeology of Kazakhstan. Vol. 2 (pp. 153-161). Almaty - Moscow: Ghylym. Original in Russian (3yев, Ю. А. Древнетюркская социальная терминология в китайском тексте VIII в. В: Самашев, 3. (ред.), Вопросы археологии Казахстана. Т. 2, c. 153-161. Алматы; М.: Ғылым).

Zuev, Yu. A. 2002. Early Turks: Essays of History and Ideology. Almaty: DaikPress. Original in Russian (Зуев Ю. А. Ранние тюрки: очерки истории и идеологии. Алматы: Дайк-Пресс). 